\title{
HP-1y controls high-affinity antibody response to T-dependent antigens
}

\author{
Ngoc Ha ${ }^{1 \dagger}$, Duc-Hung Pham ${ }^{2 \dagger}$, Aliakbar Shahsafaei ${ }^{3}$, Chie Naruse ${ }^{4}$, Masahide Asano ${ }^{4}$ and To-Ha Thai ${ }^{1 *}$ \\ 1 Beth Israel Deaconess Medical Center, Department of Pathology, Harvard Medical School, Boston, MA, USA \\ ${ }^{2}$ Laboratory for Molecular Biodiscovery, Department of Pharmaceutical and Pharmacological Sciences, University of Leuven, Leuven, Belgium \\ ${ }^{3}$ Department of Pathology, Brigham and Women's Hospital, Boston, MA, USA \\ ${ }^{4}$ Advanced Science Research Center, Kanazawa University, Kanazawa, Japan
}

Edited by:

Paolo Casali, University of Texas Health Science Center San Antonio, USA

\section{Reviewed by:}

James Hagman, National Jewish Health, USA

Hong Zan, University of Texas Health Science Center San Antonio, USA

\section{*Correspondence:}

To-Ha Thai, Beth Israel Deaconess Medical Center, Department of

Pathology, Harvard Medical School, 330 Brookline Avenue, CLS-624,

Boston, MA 02215, USA

e-mail: thai@bidmc.harvard.edu

${ }^{+}$Ngoc Ha and Duc-Hung Pham have contributed equally to this work.

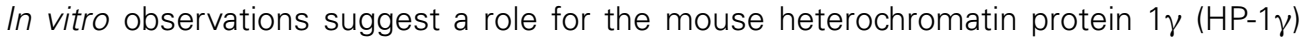
in the immune system. However, it has not been shown if and how HP-1 $\gamma$ contributes to immunity in vivo. Here we show that in mice, HP-1 $\gamma$ positively regulates the germinal center reaction and high-affinity antibody response to thymus (T)-dependent antigens by limiting the size of $\mathrm{CD}^{+}$regulatory $\mathrm{T}^{+}$-cell $\left(\mathrm{T}_{\text {reg }}\right)$ compartment without affecting progenitor B- or T-cell-development. Moreover, HP-1 $\gamma$ does not control cell proliferation or class switch recombination. Haploinsufficiency of $c b x-3$ (gene encoding HP-1 $\gamma$ ) is sufficient to expand the $\mathrm{CD}^{+} \mathrm{T}_{\text {reg }}$ population and impair the immune response in mice despite the presence of wild-type HP-1 $\alpha$ and HP-1 $\beta$. This is the first in vivo evidence demonstrating the non-redundant role of HP-1 $\gamma$ in immunity.

Keywords: chromatin remodeling, epigenetics, adaptive immunity, germinal center response, $\mathrm{CDB}^{+}$regulatory $\mathrm{T}$ cells

\section{INTRODUCTION}

The adaptive immune system allows jawed vertebrates to distinguish self from non-self, to eliminate infectious agents, and to eradicate tumors. In addition, jawed vertebrates have the unique ability to store long-term immunological memory, thus enabling a rapid and vigorous adaptive immune response against previously encountered microbes. To achieve this outcome, diverse lymphocyte populations and their effector functions must be finely orchestrated and controlled. Dysregulation of any of these processes may result in the development of autoimmune diseases, inability to resolve infections, or failure to control the outgrowth of malignant cells. Therefore, the regulation of the adaptive immune response must occur on many levels, and there still remain novel genes and pathways yet to be uncovered.

The heterochromatin protein 1 (HP-1) family includes members that associate with modified histones, indicating that HP-1 proteins are involved in epigenetic modifications. HP-1 proteins are conserved from the yeast Schizosaccharomyces pombe (S. pombe) to mammals (1-5). The mammalian HP-1 family consists of three conserved members: HP- $1 \alpha$, HP- $1 \beta$, and HP- $1 \gamma$ encoded by $c b x-5, c b x-1$, and $c b x-3$, respectively (2). Of particular significance to the immune system is the observation that HP- $1 \gamma$ is found associated with the transcription elongation complex containing RNA polymerase II (Pol II) within the coding region of the actively transcribed IL-2 gene in stimulated primary T cells (6). By contrast, during B-cell-development, HP- $1 \gamma$ associates with the silenced $\kappa$ allele implicating HP- $1 \gamma$ in allelic exclusion (7). In addition, HP- $1 \gamma$ has been found associated with both heterochromatin and euchromatin suggesting that it participates in transcriptional repression and activation, respectively $(4,8,9)$. HP- $1 \gamma$ interacts with the methyl groups of $\mathrm{H} 3 \mathrm{~K} 9$ through the chromodomain (CD) and with the methyl transferase SUV39-H1 and other proteins through the chromoshadow domain (CSD) $(2,3,10)$. Despite these crucial in vitro observations, it is not understood if and how HP$1 \gamma$ contributes to the regulation of immunity in mammals in vivo. Our interest in HP- $1 \gamma$ stems from efforts to identify novel targets of miR-155 (11). We find that HP- $1 \gamma$ expression is induced in activated mutant $B$ cells suggesting that it might be an miR-155 target.

During a thymus (T)-dependent B-cell response, activated B cells migrate into follicles of secondary lymphoid organs. A fraction of activated $\mathrm{B}$ cells mediate a primary antibody $(\mathrm{Ab})$ response through differentiation into plasma cells, others are recruited to the germinal center (GC) reaction $(12,13)$. In the GC, a specialized structure within the follicle, $\mathrm{B}$ cells undergo massive proliferation accompanied by class switch recombination (CSR) and somatic hypermutation (SHM) of rearranged immunoglobulin (Ig) V region genes. SHM leads to the acquisition of mutations that increase $\mathrm{Ab}$ affinity to the immunizing antigen $(\mathrm{Ag})$, a process known as affinity maturation $(12,14,15)$. The production of highaffinity, isotype-switched $\mathrm{Ab}$ is crucial for the clearance of many infectious pathogens and provides the basis for humoral immunity and vaccine efficacy.

Resident GC T follicular helper $\left(\mathrm{T}_{\mathrm{FH}}\right)$ cells make up a specialized subset of effector $\mathrm{CD} 4^{+} \mathrm{T}$ cells that are pivotal in affinity maturation by selecting activated $\mathrm{B}$ cells to enter the GC, regulating GC positive selection, and directing B-cell differentiation to plasma cells and memory B cells (16-18). Within the GC, $\mathrm{T}_{\mathrm{FH}}$ cells develop in concert with GC B cells (19-24). 
Early observations show that a subset of effector $\mathrm{CD} 8^{+} \mathrm{T}$ cells can suppress T-cell help to B cells (25). Recent studies demonstrate that these $\mathrm{CD}^{+}$regulatory $\mathrm{T}\left(\mathrm{T}_{\mathrm{reg}}\right)$ cells control GC reaction and high-affinity $\mathrm{Ab}$ response to foreign $\mathrm{T}$-dependent Ags as well as self-Ags by limiting the size of the $\mathrm{T}_{\mathrm{FH}}$ compartment $(26,27)$. In mice, genetic disruption of the inhibitory interaction between $\mathrm{CD}^{+} \mathrm{T}_{\text {reg }}$ cells and their target $\mathrm{Qa}-1^{+} \mathrm{T}_{\mathrm{FH}}$ cells results in the development of systemic lupus erythematosus (SLE)-like autoimmune disease and the inability to mount a high-affinity $\mathrm{Ab}$ response to T-dependent Ags. These studies reveal the central role that $\mathrm{CD}^{+} \mathrm{T}_{\text {reg }}$ cells play in the control of the adaptive immune response. However, mechanisms that regulate the development and/or homeostasis of these cells remain elusive.

In this study, we uncover a novel molecular pathway that regulates the adaptive immune response to T-dependent Ags. We demonstrate that HP- $1 \gamma$ positively controls the GC reaction and high-affinity $\mathrm{Ab}$ response. $\mathrm{HP}-1 \gamma$ does so by limiting the size of the $\mathrm{CD}^{+} \mathrm{T}_{\text {reg }}$ compartment. Haploinsufficiency of $c b x-3$ results in the expansion of $\mathrm{CD}^{+} \mathrm{T}_{\text {reg }}$ cells and impaired immune response.

\section{RESULTS}

\section{B- OR T-CELL-DEVELOPMENT IS NOT AFFECTED BY HP- $1 \gamma$ DEFICIENCY}

Although in vitro studies suggest a role for HP- $1 \gamma$ in the immune system, it has not been determined if it contributes to immunity in vivo. The $c b x-3$ (gene encoding HP-1 $\gamma$ ) mutant mouse was generated by gene-trapping technology as described previously (10, 28 ). We found that $c b x-3^{-1-}$ mice died perinatally. Because haploinsufficiency of genes involved in epigenetic modifications has been shown to alter cellular functions (29), we asked if haploinsufficiency of $c b x-3$ was sufficient to affect the immune system. First we assessed if $c b x-3$ deficiency influenced progenitor lymphoid development. A survey of the bone marrow (BM) and thymus showed that progenitor $\mathrm{B}$ and $\mathrm{T}$ cells developed normally in $c b x$ $3^{+/-}$mice compared to littermate controls (Figures 1A,B). Mature $\mathrm{B}-$ and T-cell-development also remained normal in $c b x-3^{+/-}$ mice (Figures 1C,D). Thus, HP- $1 \gamma$ is not required for progenitor or mature B- and T-cell-development.

\section{HP-1 $\gamma$ DEFICIENCY RESULTS IN IMPAIRED GERMINAL CENTER REACTION}

To determine the physiological function of HP- $1 \gamma$ in the adaptive immune response in mice, we immunized littermate control and $c b x-3^{+/-}$mice with the T-dependent Ag 4-hydroxy-3nitrophenylacetyl hapten conjugated to chicken gamma globulin (NP-CGG) in alum. On day 14 after immunization, the expected frequency of spleen $\mathrm{B} 220^{+} \mathrm{CD} 38^{\mathrm{lo} /-} \mathrm{FAS}^{+} \mathrm{GC}$ as well as switched $\mathrm{B} 220^{+} \mathrm{CD} 38^{\mathrm{lo} /-} \mathrm{IgG}_{1}^{+}$B cells was obtained from littermate controls, demonstrating that the GC reaction occurred normally (Figure 2). In contrast, the GC response was impaired in $c b x-3^{+1-}$ mice. On day 14 , the percent of spleen GC B cells in $c b x-3^{+/-}$ mice decreased by 2.3 -fold compared to control mice $(p=0.0002$, Figures 2A,B,F). Correspondingly, there was a twofold reduction in the percent of switched $\operatorname{IgG}_{1}^{+}$spleen $\mathrm{B}$ cells in $c b x-3^{+/-}$mice compared to control mice $(p=0.0007$, Figures $2 \mathrm{~A}, \mathrm{C})$. Similarly, the frequency of $\operatorname{IgG}_{1}^{+} \mathrm{GC} \mathrm{B}$ cells in $c b x-3^{+/-}$mice was reduced by 2.8 -fold compared to wild-type littermate mice (Figures 2D,E, $p<0.0001)$. The spleen architecture of wt littermate and mutant mice remained intact; and more peanut agglutinin (PNA) positive
GCs were detected in wt littermate mice than in mutant mice on day 14 after immunization with NP (Figure 2F). These results demonstrate that $\mathrm{HP}-1 \gamma$ positively regulates the GC reaction and production of $\mathrm{IgG}_{1}^{+} \mathrm{B}$ cells, and haploinsufficiency of $c b x-3$ is sufficient to impair these processes. The defect cannot be compensated for by the presence of wild-type HP- $1 \alpha$ and HP- $1 \beta$ in $c b x-3^{+/-}$ mice suggesting that HP- $1 \gamma$ has a non-redundant function in immunity in vivo.

\section{CBX-3 $3^{+/-}$MICE FAIL TO MOUNT HIGH-AFFINITY NP ANTIBODY RESPONSE}

To determine if the diminished GC reaction in $c b x-3^{+/-}$mice results in defective serum anti-NP Ab response, we measured anti-NP activity in sera obtained from $c b x-3^{+/-}$and wt littermate mice on day 14 after NP immunization. Serum high- and low-affinity responses to NP can be measured by enzyme-linked immunosorbent assay (ELISA) using NP4 and NP25 Ags, respectively. On day 14 after immunization, serum IgG anti-NP25 Ab activity increased in littermate control and mutant mice compared to unimmunized animals, and the level was similar between the two groups. By contrast, the amount of serum anti-NP4 antibodies in littermate control mice was 4.75 -fold higher than $c b x-3^{+/-}$ mice $(p=0.006$, Figure 3A). Accordingly, the ratio of NP4/NP25 $\mathrm{Ab}$ titer was threefold lower in $c b x-3^{+/-}$mice compared to littermate control mice ( $p=0.02$, Figure 3B). The low-affinity response was not affected by $c b x-3$ haploinsufficiency. Both littermate control and mutant mice produced low amounts of serum IgM Abs against NP, and the majority of IgM antibodies were of low-affinity (Figures 3C,D). There was no difference in the production of total pre-immune serum IgG $\mathrm{I}_{1}$ and IgM between wt littermate control and mutant mice (Figure 3E). Thus $c b x-3^{+/-}$mice could not mount high-affinity $\mathrm{Ab}$ response to NP.

\section{HP-1 $\gamma$ DOES NOT REGULATE B-CELL PROLIFERATION OR CLASS SWITCH RECOMBINATION}

To rule out the possibility that reduced $\mathrm{GC}$ and $\mathrm{Ab}$ responses resulted from defects in proliferation or class switching after Ag encounter, we carried out in vitro proliferation/switch assays. Spleen B cells from $c b x-3^{+/-}$mice proliferated and switched as well as littermate control B cells when activated through the B-cell receptor, Toll-like receptor (TLR) 4, or CD40 plus IL-4 (Figures 4A,B). Therefore, HP- $1 \gamma$ deficiency results specifically in impaired high-affinity, not total NP Ab response. HP-1 $\gamma$ does not control the IgM response to NP. Because HP-1 $\gamma$ deficiency does not perturb proliferation or switching, the defect in high-affinity $\mathrm{Ab}$ response observed in $c b x-3^{+/-}$mice implies that HP- $1 \gamma$ may regulate $\mathrm{Ab}$ affinity maturation.

\section{THE T FOLLICULAR HELPER CELL POPULATION IS REDUCED IN CBX-3 ${ }^{+/-}$MICE}

$\mathrm{T}$ follicular helper cells play a crucial role in affinity maturation in part by selecting B cells to enter the GC, regulating GC positive selection, and directing B-cell differentiation to plasma cells and memory B cells. Hence, the high-affinity Ab response defect seen in $c b x-3^{+1-}$ mice may arise from inefficient $\mathrm{T}_{\mathrm{FH}}$ support. Fluorescence-activated cell sorting (FACS) analysis showed that as the immune response proceeded to day 14, the frequency of TCR $\beta^{+}{ }^{+} \mathrm{CD} 4^{+}{ }^{+} \mathrm{CXCR} 55^{\text {hi }} \mathrm{PD}-1^{\text {hi }} \mathrm{T}_{\mathrm{FH}}$ cells decreased by 1.7 -fold in 


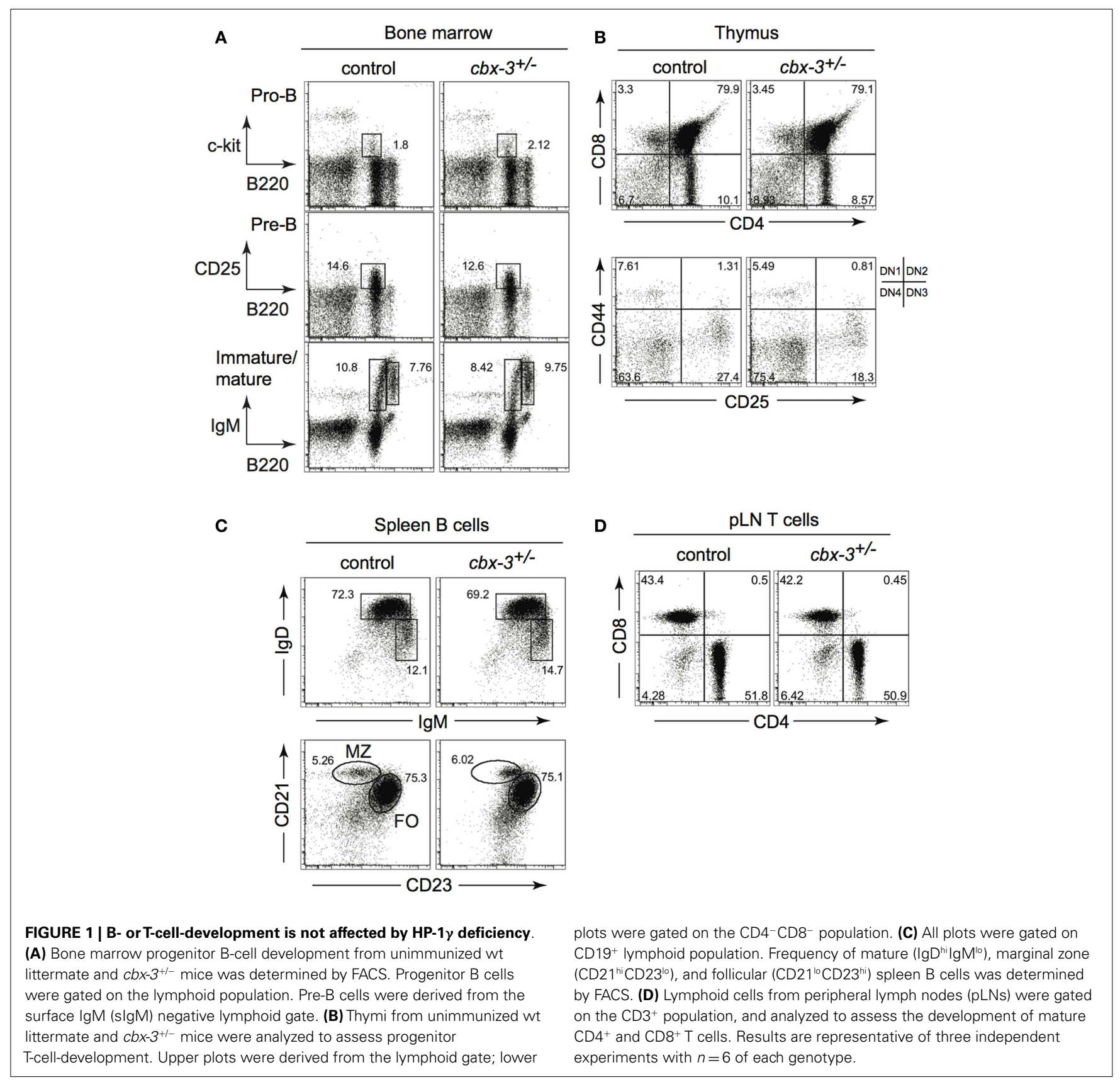

$c b x-3^{+/-}$mice compared to wt littermate control mice $(p<0.0001$, Figures 5A,B). Moreover, we did not detect any differences in Bcl6, Prdm1, or Aicda expression between wt littermate control and mutant mice suggesting that GC and plasma cell differentiation was not affected by HP- $1 \gamma$ deficiency (data not shown). Thus, $\mathrm{HP}-1 \gamma$ governs $\mathrm{Ab}$ affinity maturation perhaps by controlling the size of the $\mathrm{T}_{\mathrm{FH}}$-cell compartment during an immune response to T-dependent Ags.

\section{THE GC REACTION DEFECT IN CBX-3+/- MICE IS NOT INTRINSIC TO B OR T TH CELLS}

To determine if $\mathrm{T}_{\mathrm{FH}}$ cells were directly responsible for the GC phenotype observed, we generated $c b x-3^{+/+} / c b x-3^{+/-}$mixed BM chimeras. Recombinase activating gene 2 and common $\gamma$ chain double knock out (B6-Rag2 ${ }^{-/-} \mathrm{C \gamma}^{-/-}$) mice were reconstituted with a 1:1 mix of either CD45.1 $c b x-3^{+/+} / \mathrm{CD} 45.2 c b x-3^{+/+}$or CD45.1 $c b x-3^{+/+} / \mathrm{CD} 45.2 c b x-3^{+/-}$BM. Eight weeks after reconstitution chimeric mice were immunized with NP-CGG in alum. On day 14 after immunization, mice were analyzed to determine the frequency of GC B cells, switched $\operatorname{IgG}_{1}^{+} \mathrm{B}$ cells and $\mathrm{T}_{\mathrm{FH}}$ cells derived from CD45.2 (control $c b x-3^{+/+}$or $c b x-3^{+/-}$) donor BM in each mouse (Figure 6A). FACS analysis showed that CD45.2 $c b x$ $3^{+/+}$and CD45.2 $c b x-3^{+/-}$chimeric mice had similar percentage of GC and $\mathrm{IgG}_{1}^{+} \mathrm{B}$ cells as well as $\mathrm{T}_{\mathrm{FH}}$ cells (Figure 6B). Therefore, the GC defect observed in $c b x-3^{+/-}$is not intrinsic to $\mathrm{B}$ or $\mathrm{T}_{\mathrm{FH}}$ cells. 

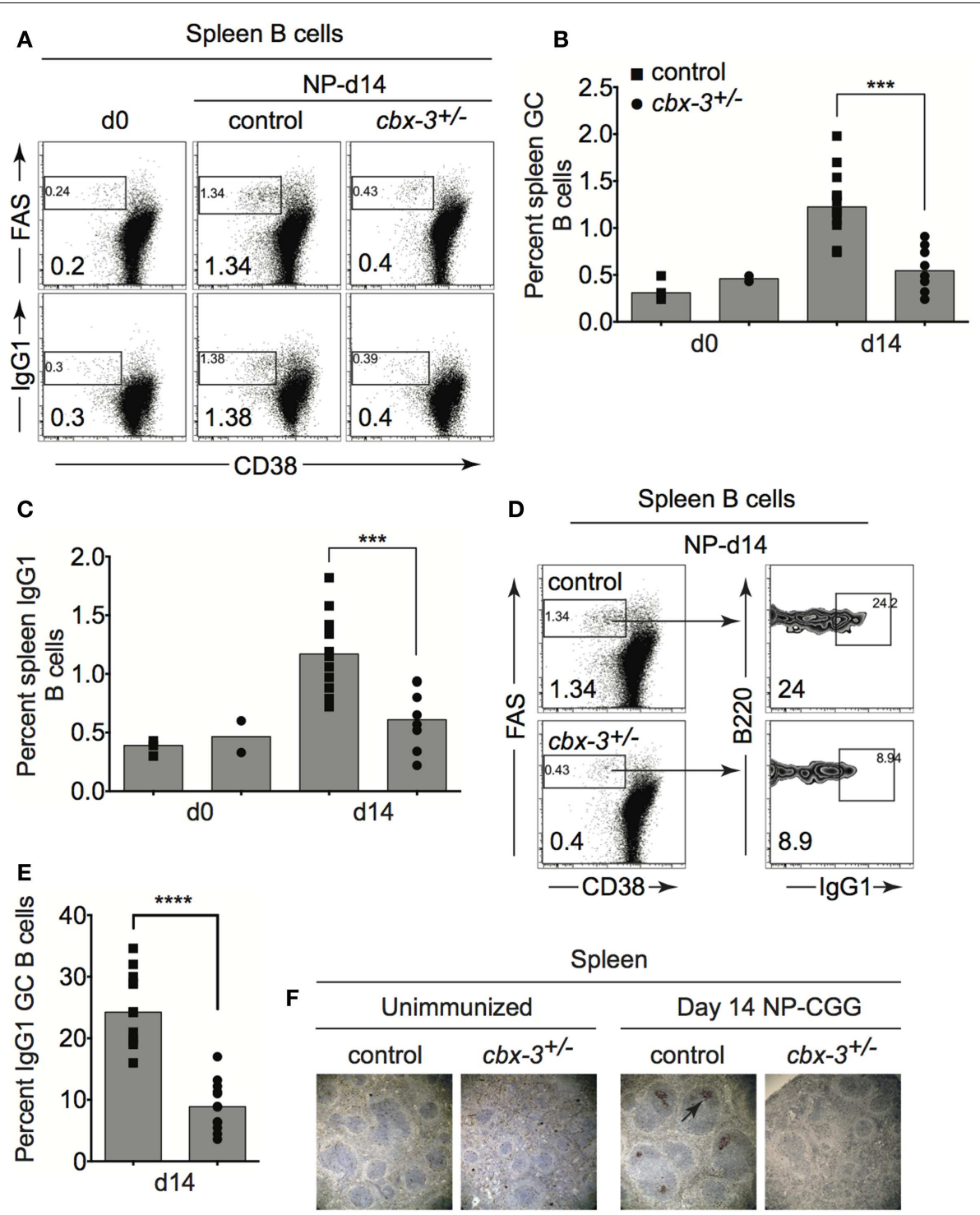

FIGURE 2 | Heterochromatin protein $1 \gamma$ deficiency results in impaired germinal center reaction. (A) Wt littermate and $c b x-3^{+/-}$mice were immunized with NP-CGG in alum. On day 14 after immunization, mice were analyzed by FACS to determine the frequency of spleen

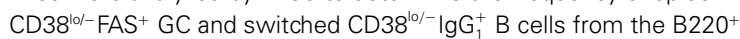
gate. Numbers in left bottom corners indicate percent cells. (B) Plot depicts the compilation of GC B-cell frequency from experiments in (A) Each symbol represents an individual mouse. Bars represent median $*^{* *} p=0.0002$. (C) Plot summarizes switched $\operatorname{lgG}_{1}$ B-cell frequency from experiments in (A). Bars represented median ${ }^{* *} p=0.0007$. Each symbol represents an individual mouse. (D) Frequency of $\operatorname{lgG}_{1}^{+} \mathrm{GC} B$ cells was determined from (A), gated on B220+CD38 ${ }^{\mathrm{lo}-}$ FAS ${ }^{+} \mathrm{GC}$ B cells. Numbers in left bottom corners indicate percent cells. (E) Plot summarizes the percent $\operatorname{lgG}_{1}^{+} \mathrm{GC} B$ cells from (D). Bars represent median, ${ }^{* * *} p<0.0001$. Each symbol represents an individual mouse. (F) Immunohistochemistry of spleen sections from unimmunized and day 14 NP-immunized mice were stained for PNA (brown) to detect GCs (arrow). Spleens were from mice in (A). Images are shown at $100 \times$ magnification. Statistical analysis was performed with GraphPad one-way ANOVA. $N=8-12$ for each genotype.

\section{CD122 ${ }^{+}$LY $49+^{+}$CD3 $^{+}$CD8 $^{+}$REGULATORY T-CELL COMPARTMENT IS EXPANDED IN $\mathbf{C B X}-3^{+/-}$MICE}

Recently, Kim and colleagues showed that CD122 ${ }^{+} \mathrm{Ly}_{49}{ }^{+} \mathrm{CD} 3^{+}$ $\mathrm{CD}^{+}$regulatory $\mathrm{T}\left(\mathrm{T}_{\text {reg }}\right)$ cells served to inhibit the expansion of $\mathrm{T}_{\mathrm{FH}}$ population during an immune response to foreign Ags as well as to self-Ags $(26,27)$. Thus it is plausible that reduction in the $\mathrm{T}_{\mathrm{FH}}$ compartment in $c b x-3^{+/-}$mice may be due to an increase in $\mathrm{CD}^{+} \mathrm{T}_{\text {reg }}$ cells within the $\mathrm{CD}^{+}{ }^{+} \mathrm{T}$-cell compartment. On days
7 and 14 after immunization, compared to wt littermate mice, $c b x-3^{+/-}$mice had 2.3- and 1.8-fold higher frequency of spleen $\mathrm{CD}^{+} \mathrm{T}_{\text {reg }}$ cells, respectively $(p<0.0001$, Figures 7A,B). Correspondingly, the number of spleen $\mathrm{CD}^{+} \mathrm{T}_{\text {reg }}$ cells in $c b x-3^{+/-}$ mice increased by 1.8 - and 1.75-fold on days 7 and 14, respectively $(p<0.0001$, Figure 7C). Next, western blots were carried out to assess the expression status of $\mathrm{HP}-1 \gamma$ in mutant $\mathrm{CD} 8^{+}$ T cells. To our surprise, $\mathrm{CD}^{+}$and $\mathrm{CD}^{+}{ }^{+} \mathrm{T}$ cells as well as $\mathrm{B}$ 


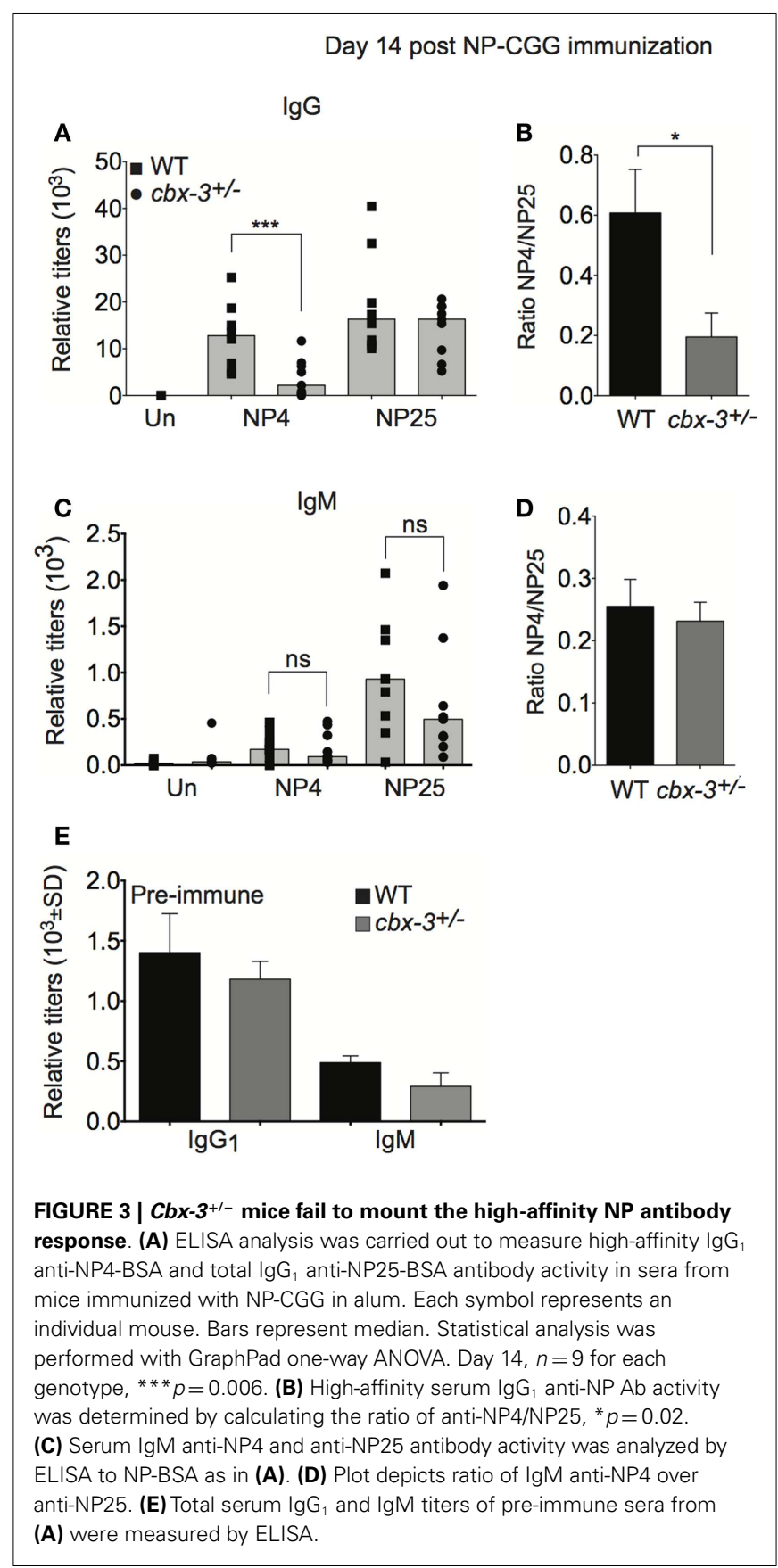

cells from $c b x-3^{+1-}$ mice expressed much less HP- $1 \gamma$ than control cells despite the presence of one wild-type allele (Figure 7D). To ensure that the expansion of $\mathrm{CD}^{+} \mathrm{T}_{\text {reg }}$ cells in $c b x-3^{+/-}$mice was intrinsic to the $\mathrm{CD} 8^{+} \mathrm{T}$-cell population, mixed $\mathrm{BM}$ chimeras were generated as described in Figure 6A. Mice were allowed to reconstitute for 8 weeks. On day 14 after immunization, reconstituted mice were analyzed to assess the frequency of $\mathrm{T}_{\text {reg }}$ cells derived from CD45.2 (control $c b x-3^{+/+}$or $c b x-3^{+/-}$) donor BM in each mouse. As shown in Figure 7E, CD45.2 $c b x-3^{+/-}$chimeric mice had 4.6-fold more $\mathrm{CD}^{+} \mathrm{T}_{\text {reg }}$ cells than CD45.2 $c b x-3^{+/+}$control mice. Thus, the $\mathrm{CD}^{+} \mathrm{T}_{\text {reg }}$ population expanded in $c b x-3^{+/-}$ mice. These results suggest that HP- $1 \gamma$ limits the size of $\mathrm{CD}^{+} \mathrm{T}_{\text {reg }}$ cells during an immune response, and the effects are intrinsic to these cells.

\section{CBX-3 ${ }^{+/-}$CD8 ${ }^{+}$REGULATORY T CELLS DIRECTLY CONTROL T-DEPENDENT IMMUNE RESPONSE}

To investigate if $\mathrm{CD}^{+} \mathrm{T}_{\text {reg }}$ cells from $c b x-3^{+/-}$mice directly controlled the $\mathrm{Ab}$ response, adoptive transfers into $\mathrm{B} 6-\mathrm{Rag}^{-1-} \mathrm{c \gamma}^{-1-}$ recipients were performed. Group 1 (control) recipients received $\mathrm{B}$ cells, $\mathrm{CD}^{+}{ }^{+}$and $\mathrm{CD} 8^{+} \mathrm{T}$ cells from wt littermate mice; group 2 (experimental) received $\mathrm{B}$ cells and $\mathrm{CD} 4^{+} \mathrm{T}$ cells from wt littermate mice, and $\mathrm{CD}^{+} \mathrm{T}$ cells from $c b x-3^{+/-}$mice; group 3 (control) received $\mathrm{B}$ cells and $\mathrm{CD}^{+} \mathrm{T}$ cells from wt littermate mice, and $\mathrm{CD}^{+} \mathrm{T}$ cells from $c b x-3^{+/-}$mice (Figure 8A). On day 10 after immunization with NP-CGG in alum, recipients were analyzed to assess the status of the GC response. The percent of GC B cells from group 2 was 2.2-fold lower than groups 1 and $3(p=0.04$ and $p=0.02$, respectively, Figure 8B). Additionally, group 2 recipients had 1.7 - and 1.9 -fold less $\mathrm{T}_{\mathrm{FH}}$ cells than groups 1 and 3, respectively (Figure 8C). By contrast, the frequency of $\mathrm{CD}^{+} \mathrm{T}_{\text {reg }}$ cells from group 2 was three- and fourfold higher than groups 1 and 3, respectively (Figures 8D,E). Thus, HP- $1 \gamma$-deficient $\mathrm{CD}^{+} \mathrm{T}$ cells alone have the propensity to reduce the $\mathrm{GC}$ response. The results suggest that HP- $1 \gamma$ positively regulates GC and highaffinity $\mathrm{Ab}$ responses to T-dependent Ags by curtailing the ability of $\mathrm{CD}^{+} \mathrm{T}$ cells to inhibit an immune response.

\section{DISCUSSION}

The regulation of the adaptive immune response is multilayered, requiring the participation of multiple cells and their proper functions. Here we uncover a novel function for the chromatin-remodeling factor HP- $1 \gamma$ in governing immunity.

$C b x-3$ was cloned nearly two decades ago and yet very little is known of its physiological function in the mammalian immune system (30). Our results reveal an essential role for HP-1 $\gamma$ in the control of the adaptive immune response in mice. We demonstrate that HP- $1 \gamma$ has a positive impact on the GC reaction and high-affinity $\mathrm{Ab}$ response to T-dependent Ags. Mainly, $c b x-3^{+/-}$ mice fail to mount an effective GC reaction and high-affinity $\operatorname{IgG}_{1}$ $\mathrm{Ab}$ response, whereas the low-affinity $\operatorname{IgG}_{1} \mathrm{Ab}$ response remains intact. The GC reaction and high-affinity response defects are accompanied by a reduction in the $\mathrm{T}_{\mathrm{FH}}$ compartment. The fact that neither low-affinity $\operatorname{IgG}_{1}$ Ab nor IgM response is affected in $c b x-3^{+/-}$mice indicates that HP-1 $\gamma$ may not be essential for extrafollicular reaction. The presence of wild-type HP- $1 \alpha$ and $\mathrm{HP}-1 \beta$ proteins cannot override defects in GC reaction and highaffinity $\mathrm{Ab}$ response seen in $c b x-3^{+/-}$mice suggests that HP- $1 \gamma$ has a non-redundant regulatory function in immune response to T-dependent Ags. The function of HP- $1 \gamma$ in immune response is not intrinsic to $\mathrm{B}$ or $\mathrm{T}_{\mathrm{FH}}$ cells.

In vitro observations suggest that $\mathrm{HP}-1 \gamma$ associates with the silenced $\kappa$ allele thus may be involved in light chain allelic exclusion during B-cell-development (7). Our results demonstrate that light chain allelic exclusion and B-cell-development in the BM occur normally in $c b x-3^{+/-}$mice. However, our data do not rule out the possibility that other HP-1 proteins, HP- $1 \alpha$ and HP- $1 \beta$, may compensate for HP-1 $\gamma$ deficiency during B-cell-development. 

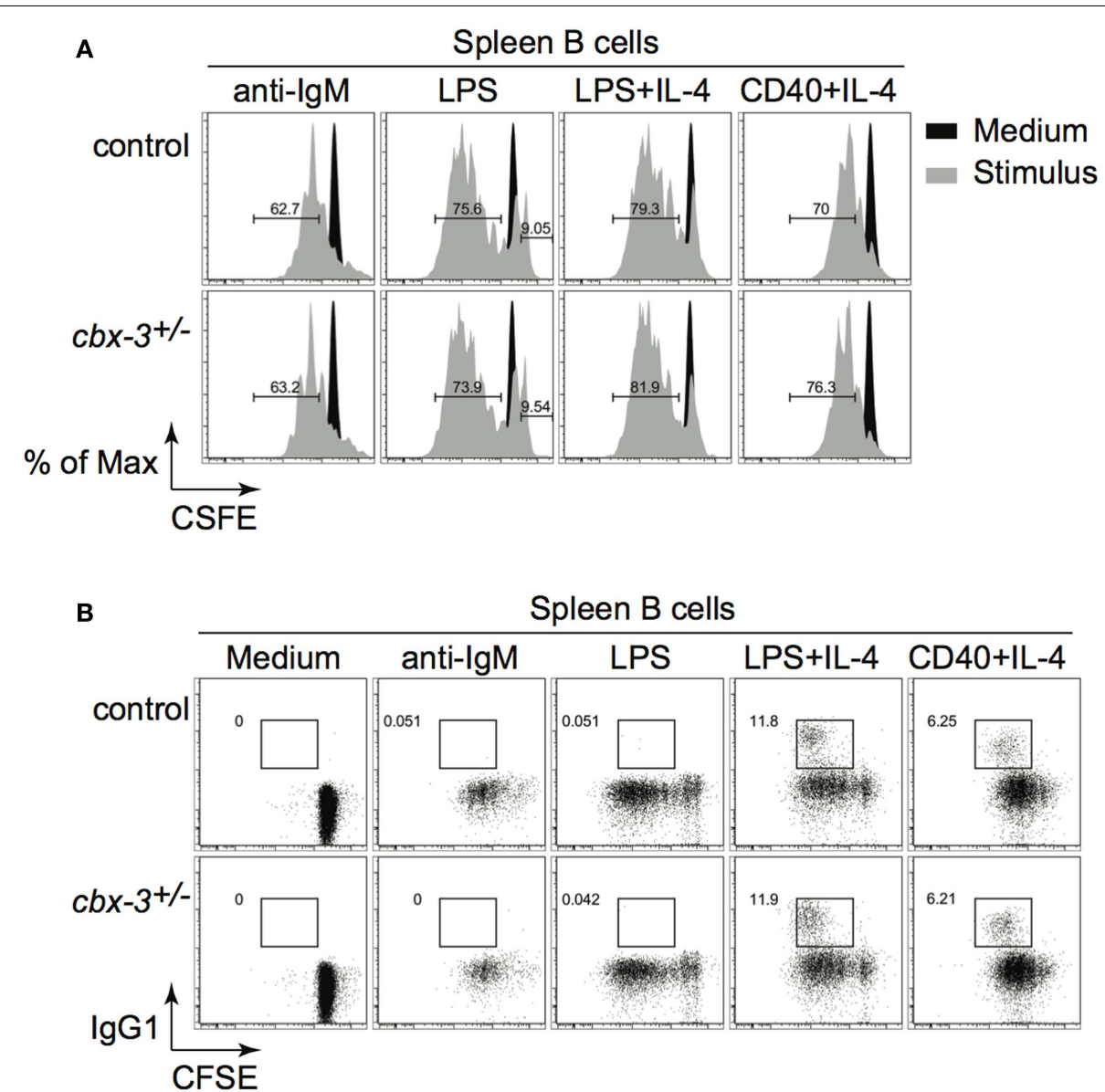

FIGURE 4 | Heterochromatin protein $1 \boldsymbol{\gamma}$ does not regulate B-cell proliferation or class switch recombination. (A) Naïve spleen B cells were labeled with CFSE and stimulated with various stimuli for 3 days. Cell division was determined using the FlowJo Proliferation Platform software. (B) $\operatorname{lgG}_{1}$ switching was determined from the same cultures as in (A). Results are representative of three independent experiments with six mice per genotype. Analysis was performed on cells derived from the live gate.
Recent studies have shown that a subpopulation of effector $\mathrm{CD}^{+} \mathrm{T}$ cells, known as $\mathrm{CD} 8^{+} \mathrm{T}_{\text {reg }}$ cells, control GC reaction and high-affinity $\mathrm{Ab}$ response to foreign $\mathrm{T}$-dependent Ags as well as self-Ags by limiting the size of the $\mathrm{T}_{\mathrm{FH}}$ compartment (27). However, mechanisms that regulate the development or homeostasis of these cells remain elusive. Here, we reveal a novel molecular pathway that controls $\mathrm{CD}^{+} \mathrm{T}_{\text {reg }}$ cells in mice after immunization. We show that, through its non-redundant function, HP- $1 \gamma$ limits the size of the $\mathrm{CD}^{+} \mathrm{T}_{\text {reg }}$ population thus allowing the immune response to foreign T-dependent Ags to proceed. In mice, HP-1 $\gamma$ deficiency results in the expansion of these cells and reduction of $\mathrm{T}_{\mathrm{FH}}$ population, which leads to the abrogation of GC reaction and high-affinity Ab response. The level of HP-1 $\gamma$ present in mutant cells is much less than expected despite the presence of one wild-type allele, implying that HP- $1 \gamma$ may also regulate its own expression. HP- $1 \gamma$ deficiency only affects CD8 ${ }^{+}$T-cell function despite the fact that mutant $\mathrm{CD}^{+}$and $\mathrm{B}$ cells also express low amounts of HP- $1 \gamma$, suggesting that in these cells HP$1 \gamma$ may regulate the expression of genes that are not essential to NP-response.
It remains to be determined how HP-1 $\gamma$ controls the development/homeostasis of $\mathrm{CD}^{+} \mathrm{T}_{\text {reg }}$ cells, and if HP- $1 \gamma$ deficiency would alleviate autoimmunity. We speculate that HP- $1 \gamma$ may control the expression and/or function of a transcription factor(s), which governs $\mathrm{CD}^{+} \mathrm{T}_{\text {reg }}$ development/homeostasis. HP- $1 \gamma$ does so perhaps by maintaining a chromatin conformation that is unfavorable to the expression and/or function of this putative transcription factor(s). Future genome wide experiments will allow us to map the changing epigenomic landscape in HP- $1 \gamma$ sufficient and deficient $\mathrm{CD}^{+} \mathrm{T}$ cells. These ongoing studies will expand our understanding of mechanisms by which HP- $1 \gamma$, through its ability to remodel the chromatin, regulates immunity.

In summary, this study shows for the first time that in mice the non-redundant regulatory function of HP- $1 \gamma$ governs GC and high-affinity $\mathrm{Ab}$ responses by limiting the pool of $\mathrm{CD} 8^{+} \mathrm{T}_{\text {reg }}$ cells.

\section{MATERIALS AND METHODS}

\section{MICE}

cbx-3 mutant mice were generated, as described in Ref. (10, 28). Mice were backcrossed to C57BL/6 for 12 generations. 

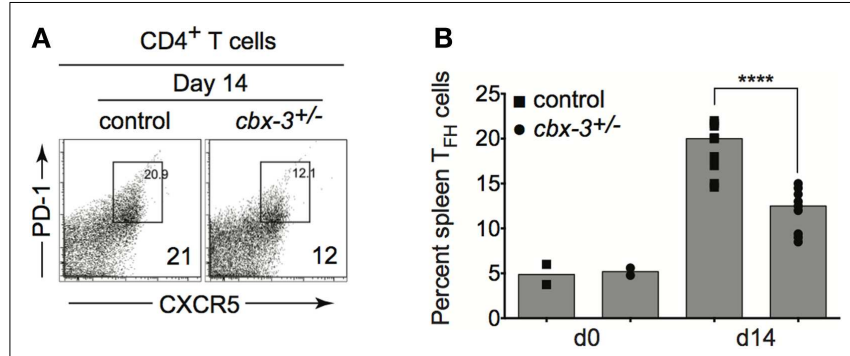

FIGURE 5 |The T follicular helper cell copulation is reduced in $\boldsymbol{c b} \mathbf{b}-\mathbf{3}^{+/-}$mice. (A) The frequency of spleen TCR $\beta^{+} C D 4^{+} C X C R 5^{\text {hi }} P D-1^{\text {hi }} T_{F H}$ population was determined by FACS analysis. Numbers in right bottom corners indicate the percent cells. CXCR5 ${ }^{\text {hi }} P D-1^{\text {hi }} T_{F H}$ cells were gated on the TCR $\beta^{+} \mathrm{CD} 4^{+}$population. (B) Plot represents a compilation of the percent of $\mathrm{T}_{\mathrm{FH}}$ population from (A). Each symbol denotes an individual mouse. Bars represent median. Statistical analysis was performed with GraphPad one-way ANOVA. Day 14, $n=8-12$ for each genotype, **** $p<0.0001$.

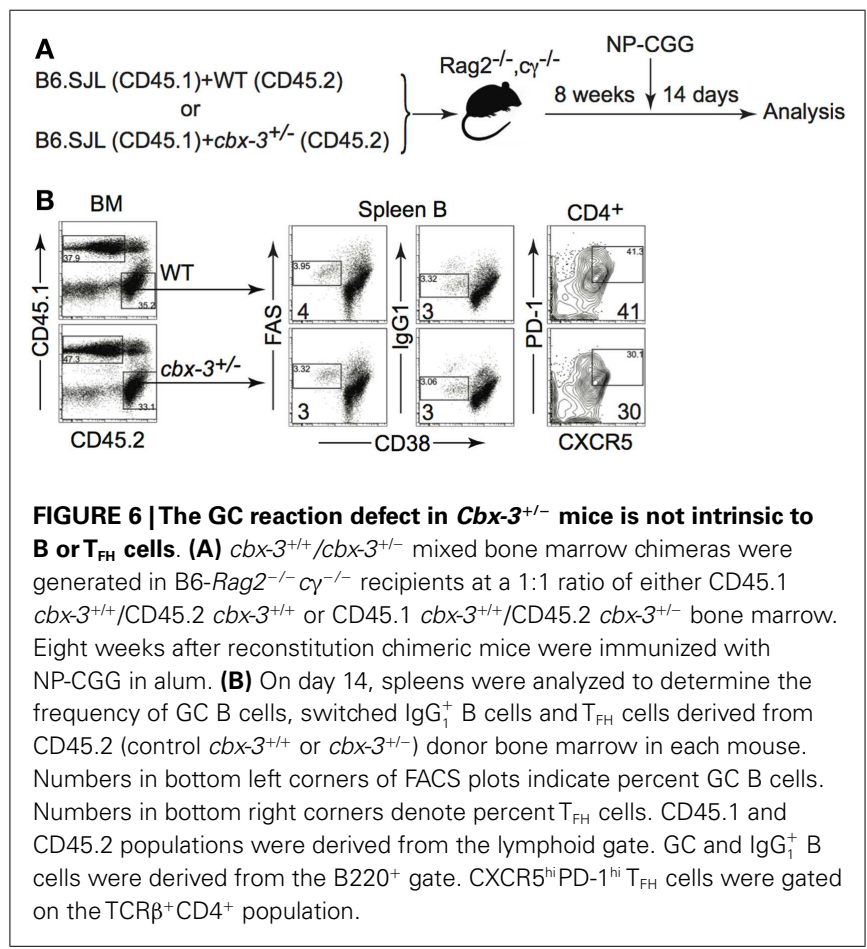

B6-Rag2-/- $C \gamma^{-/-}$and B6.SJL mice were purchased from Taconic. All mice were maintained in specific pathogen-free conditions. All mouse protocols were approved by the BIDMC Institutional Animal Care and Use Committee.

\section{FLUORESCENCE-ACTIVATED CELL SORTING}

Fluorescence-activated cell sorting was performed on the BD 5laser LSR II. Analysis was carried with FlowJo software (Tree Star, Inc.). All fluorochrome-conjugated antibodies were purchased from Biolegend or BD Biosciences. The following antibodies were used: ckit-APC (1:200); CD25-PE (1:200); IgM-FITC
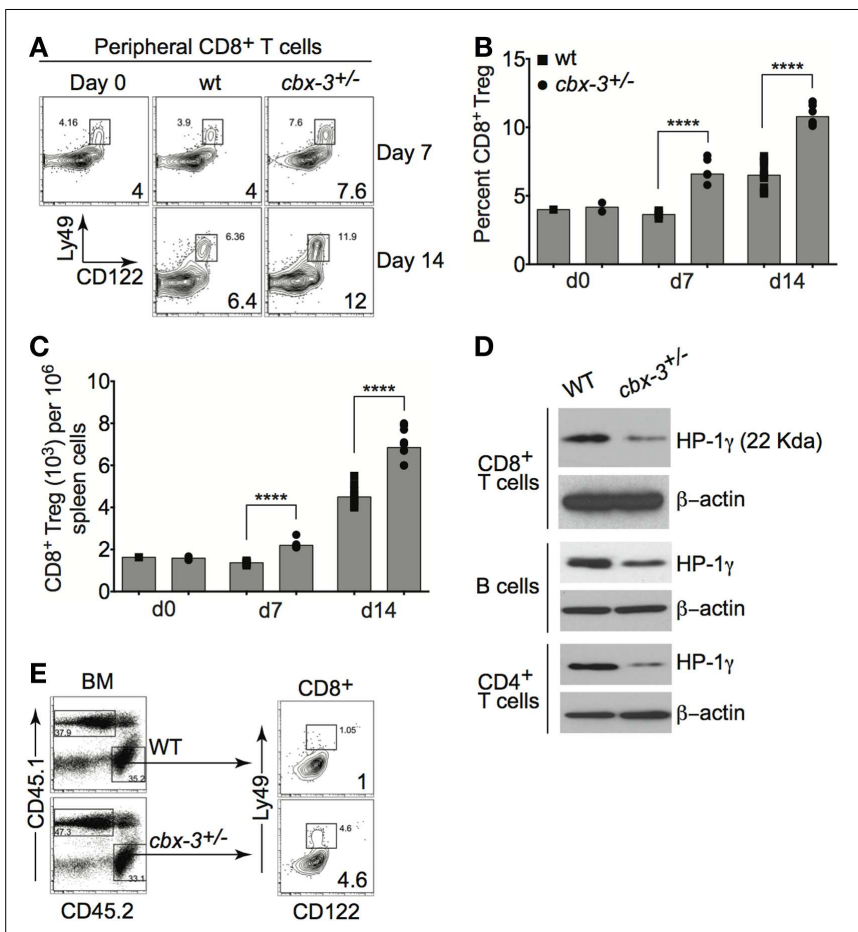

FIGURE 7 | $\mathrm{CD}^{2} 22^{+} \mathrm{Ly}_{49}{ }^{+} \mathrm{CD}^{+} \mathrm{CD}^{+}$regulatory T-cell compartment is expanded in $\boldsymbol{c b x}-\mathbf{3}^{+/-}$mice. (A) On days 7 and 14 after immunization, percent of spleen $\mathrm{CD} 122+\mathrm{Ly} 49+\mathrm{CD} 3{ }^{+} \mathrm{CD} 8+$ regulatory $\mathrm{T}$-cell $\left(\mathrm{T}_{\text {reg }}\right)$ population from wt littermate and $c b x-3^{+/-}$mice was assessed by FACS. Numbers in lower right corners indicate percent cells. CD122 ${ }^{+} \mathrm{Ly} 49^{+} \mathrm{CD} 8^{+} \mathrm{T}_{\text {reg }}$ cells were gated on the $\mathrm{CD}^{+}$population. $(\mathbf{B}, \mathbf{C})$ Plots represent a compilation of the percent and number of $\mathrm{CD}^{+} \mathrm{T}_{\text {reg }}$ population from (A). Each symbol denotes an individual mouse. Bars represent median. Statistical analysis was performed with GraphPad one-way ANOVA. Day 7, $n=5$ for each genotype; ${ }^{* * *} p<0.0001$. Day $14, n=8-12$ for each genotype; ${ }^{* * *} p<0.0001$. (D) Purified CD8 ${ }^{+} \mathrm{CD} 44^{-}, \mathrm{CD} 4^{+} \mathrm{CD} 25^{-}$, and $\mathrm{CD} 43^{-}$B cells were collected from spleen and peripheral lymph nodes. Blots were probed with anti-total HP- $1 \gamma(22 \mathrm{kDa}$ ) and anti- $\beta$-actin ( $42 \mathrm{kDa}$ ). Results are representative of two independent experiments; $n=4$ mice of each genotype. (E) $c b x-3^{+/+} / c b x-3^{+/-}$mixed bone marrow chimeras were generated as in Figure 6A. Percent $\mathrm{CD}^{+} \mathrm{T}_{\text {reg }}$ cells were determined by FACS. Numbers in lower right corners indicate percent cells. CD45.1 and CD45.2 populations were derived from the lymphoid gate.

$\mathrm{CD} 122^{+} \mathrm{Ly}_{49}{ }^{+} \mathrm{CD}^{+} \mathrm{T}_{\text {reg }}$ cells were gated on the $\mathrm{CD} 3^{+}$population.

(1:500); CD8-Pacific blue (1:200); CD8-APC-Cy7 (1:300); CD8PE-Cy7 (1:200); Ly-49-FITC (1:100); CD44-Pacific blue (1:200); IgD-PE (1:500); CD21-APC (1:200); CD23-PE (1:150); CD19PE-Cy7 (1:300); B220-Pacific blue (1:300); CD38-APC (1:200); IgG1-FITC (1:50); FAS-PE (1:200); CD4-FITC (1:200); CD4-PE (1:150); TCR $\beta$-Brilliant-Violet 412 (1:200); PD1-PE-Cy7 (1:100); CXCR5-Biotin (1:100); SA-PerCP (1:100); CD45.1-FITC (1:150); CD45.2-PE-Cy7 (1:100); CD45.2-Pacific blue (1:200); CD3-APC (1:200); CD122-Pacific blue (1:200).

\section{T-DEPENDENT IMMUNE RESPONSE}

Adult mice (7-8-week-old) were immunized with $50 \mu \mathrm{g}$ of the Tdependent Ag 4-hydroxy-3-nitrophenylacetyl hapten conjugated to chicken gamma globulin (NP-CGG, BioSearch Technologies) per mouse in alum (Thermo Scientific) (ratio 1:1). Immune sera 

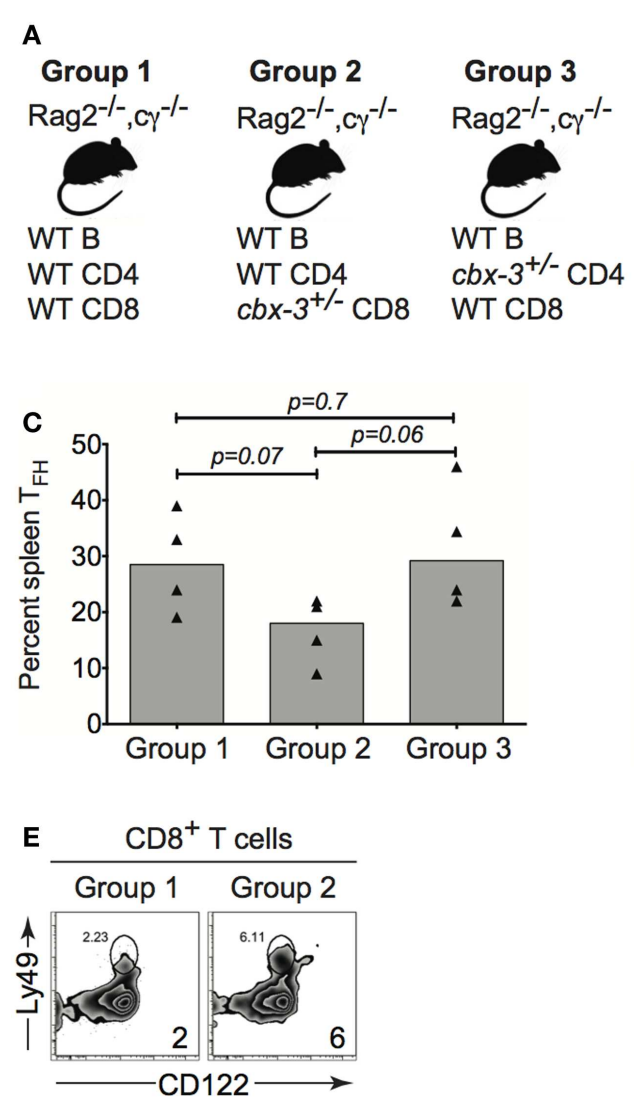

FIGURE 8 | $\mathrm{Cbx}_{-3^{+/-}} \mathrm{CDB}^{+} \mathrm{T}$ cells directly control the T-dependent immune response. (A) Purified wt or $c b x-3^{+/-}$spleen and $\mathrm{pLN}$ lymphocytes

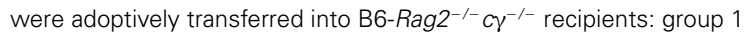
(control, $n=5$ ) received wt $\mathrm{B}$ cells, $\mathrm{CD} 4^{+}$and $\mathrm{CD} 8^{+} \mathrm{T}$ cells; group 2 (experimental, $n=5$ ) received $B$ cells and $\mathrm{CD} 4^{+} T$ cells from wt littermate mice and $\mathrm{CD}^{+} \mathrm{T}$ cells from $\mathrm{cbx}-3^{+/-}$mice; group 3 (control, $n=5$ ) received $\mathrm{B}$ cells and $\mathrm{CD} 8^{+} \mathrm{T}$ cells from wt littermate mice and $C D 4^{+} \mathrm{T}$ cells from

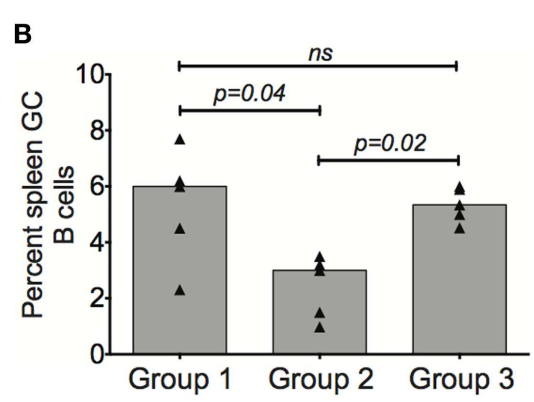

D

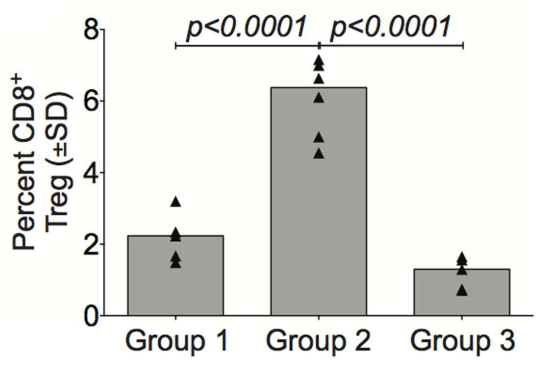

were obtained at days 7 and 14 after immunization. FACS analysis was performed on the same days.

\section{IMMUNOHISTOCHEMISTRY}

Immunohistochemistry was performed using $4 \mu \mathrm{m}$ thick formalin-fixed, paraffin-embedded tissue sections. Briefly, slides were soaked in xylene, passed through graded alcohols, and put in distilled water. Slides were then pre-treated with 1.0-mM EDTA, $\mathrm{pH} 8.0$, or $1.0 \mathrm{mM}$ citrate (Zymed) in a steam pressure cooker (Decloaking Chamber, BioCare Medical) as per manufacturer's instructions, followed by washing in distilled water. All subsequent steps were performed at room temperature in a hydrated chamber. Slides were pre-treated with Peroxidase Block (DAKO) for $5 \mathrm{~min}$ to quench endogenous peroxidase activity, followed by Serum free Protein Block (DAKO) for $20 \mathrm{~min}$. Biotinylated PNA (Vector Laboratories) was applied for $1 \mathrm{~h}$ (all diluted in DAKO diluents). Slides were washed in $50 \mathrm{mM}$ Tris-Cl, $\mathrm{pH}$ 7.4. Slides were washed again, and detected with anti-streptavidin-HRP Envision + kit (DAKO) as per manufacturer's instructions. After further washing, immunoperoxidase staining was developed using $c b x-3^{+/-}$mice. (B,C) On day 10 after NP-CGG in alum immunization, spleens of recipients were analyzed by FACS to determine the frequency of GC (from the $\mathrm{B} 220^{+}$gate) and $\mathrm{T}_{\mathrm{FH}}$ (from the $\mathrm{TCR} \beta^{+} \mathrm{CD} 4^{+}$gate) populations.

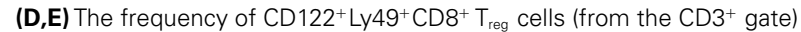
was determined by FACS (E) and plotted (D). Numbers on bottom right corners indicate percent cells. Statistical analysis was performed with GraphPad one-way ANOVA; ns, not significant. a DAB chromogen (DAKO) and counterstained with hematoxylin. Images were acquired with the Nikon Eclipse E600 and SPOT Insight four camera and software.

\section{ENZYME-LINKED IMMUNOSORBENT ASSAY}

Antibody response to NP was determined by ELISA using NP(4)BSA or NP(25)-BSA (BioSearch Technologies) from days 7 and 14 immune sera. ELISA was performed as described (11).

\section{IN VITRO B-CELL ACTIVATION AND ISOTYPE SWITCH ASSAY}

MACS-purified (Miltenyi Biotec) $\mathrm{CD}_{4} 3^{-}$or $\mathrm{CD} 19^{+} \mathrm{B}$ cells were activated in vitro at a density of $1-3 \times 10^{6} \mathrm{cells} / \mathrm{ml}$ with $2 \mu \mathrm{g} / \mathrm{ml}$ of anti-CD40 clone HM40-3 (eBiosciences) plus $25 \mathrm{ng} / \mathrm{ml}$ of recombinant mouse IL-4 (R\&D Systems), $10 \mu \mathrm{g} / \mathrm{ml}$ of goat $\mathrm{F}\left(\mathrm{ab}^{\prime}\right)_{2}$ anti-mouse IgM (Jackson Immunoresearch), LPS $(20 \mu \mathrm{g} / \mathrm{ml})$, or LPS + IL-4 (Sigma).

\section{PROLIFERATION ASSAYS AND ANALYSIS}

MACS-purified CD43- ${ }^{-}$B cells labeled with CFSE were activated with indicated stimuli as above for 3 or 4 days. Data were analyzed 
using the proliferation platform of the FlowJo software (Tree Star Inc.).

\section{GENERATION OF BONE MARROW CHIMERAS}

Bone marrow cells from femurs and tibias of 4-week-old B6.SJL mice (CD45.1) were mixed with either 4 -week-old $c b \times 3^{+/-}$or littermate control mice (CD45.2) at a 1:1 ratio. Mixed BM cells $\left(2 \times 10^{6}\right)$ were injected i.v. into 7-week-old $\mathrm{Rag} 2^{-1-} C \gamma^{-/-}$recipients. Eight weeks after BM reconstitution, recipients were immunized with NP-CGG in alum (ratio 1:1). Analysis was carried out 14 days after immunization.

\section{WESTERN BLOTS}

Purified $\mathrm{CD}^{+} \mathrm{CD}^{-}\left(1 \times 10^{6}\right)$ cells were lysed with radioimmunoprecipitation assay (RIPA) buffer (Boston BioProducts) containing protease inhibitor cocktail (Roche) on ice for $30 \mathrm{~min}$. Cells were centrifuged at $14,000 \mathrm{rpm}$ for $15 \mathrm{~min}$ at $4^{\circ} \mathrm{C}$. Protein concentration was determined by Bio-Rad Protein Assay Kit (Bio-Rad). Ten micrograms of protein extracts were denatured at $95^{\circ} \mathrm{C}$ for $10 \mathrm{~min}$, separated by SDS-PAGE, and transferred onto PVDF membranes (EMD Millipore). Membranes were probed with antibodies against HP-1 $\gamma$ (Cell Signaling Technology) or $\beta$-actin (Sigma Aldrich). Proteins of interest were detected with HRP-conjugated secondary antibodies and visualized with the Pierce ECL Western blotting substrate (Thermo Scientific).

\section{ADOPTIVE TRANSFER}

$\mathrm{B}, \mathrm{CD}^{+}$, and $\mathrm{CD} 4^{+}$cells were prepared from spleen and lymph nodes of 7 -week-old $c b \times 3^{+/-}$and wt littermate mice as described (18). $2 \times 10^{6}$ wild-type B cells, $1 \times 10^{6}$ wild-type or mutant CD8 ${ }^{+}$, and $1 \times 10^{6}$ wild-type or mutant $\mathrm{CD} 4^{+}$cells were injected i.v. into 7-week-old $\mathrm{Rag}^{-/-} \mathrm{C} \gamma^{-/-}$recipients. The following day, recipients were immunized with NP-CGG in alum (ratio 1:1). Analysis was carried out 10 days after immunization.

\section{STATISTICAL AND GRAPH ANALYSIS}

$P$ values were calculated using one-way ANOVA and graphs were plotted with Prism 6 (GraphPad Software).

\section{AUTHOR CONTRIBUTIONS}

Ngoc Ha, Duc-Hung Pham, and Aliakbar Shahsafaei carried out all experiments; Chie Naruse and Masahide Asano generated the $c b x-3$ mutant mice and provided advice on their use; To-Ha Thai conceived and directed all research, and along with Ngoc $\mathrm{Ha}$ and Duc-Hung Pham prepared the manuscript.

\section{ACKNOWLEDGMENTS}

We thank Dr. Hye-Jung Kim for advice with $\mathrm{CD}^{+} \mathrm{T}_{\text {reg }}$ experiments. We thank Mr. Arturo Contreras at the BIDMC animal facility for help with BM chimera experiments. We also thank Ms. Xue Shui for adoptive transfer experiments. We are grateful to Dr. David Nelson for editing the manuscript. This work was supported by NIH grant AI099012 and the Mayer Family Fund (To-Ha Thai).

\section{REFERENCES}

1. Singh PB, Georgatos SD. HP1: facts, open questions, and speculation. J Struct Biol (2002) 140(1-3):10-6. doi:10.1016/S1047-8477(02)00536-1
2. Lomberk G, Wallrath L, Urrutia R. The heterochromatin protein 1 family. Genome Biol (2006) 7(7):228. doi:10.1186/gb-2006-7-7-228

3. Hediger F, Gasser SM. Heterochromatin protein 1: don't judge the book by its cover! Curr Opin Genet Dev (2006) 16(2):143-50. doi:10.1016/j.gde.2006.02.013

4. Lomberk G, Bensi D, Fernandez-Zapico ME, Urrutia R. Evidence for the existence of an HP1-mediated subcode within the histone code. Nat Cell Biol (2006) 8(4):407-15. doi:10.1038/ncb1383

5. Hiragami-Hamada K, Shinmyozu K, Hamada D, Tatsu Y, Uegaki K, Fujiwara S, et al. N-terminal phosphorylation of HP1\{alpha\} promotes its chromatin binding. Mol Cell Biol (2011) 31(6):1186-200. doi:10.1128/MCB.01012-10

6. Vakoc CR, Mandat SA, Olenchock BA, Blobel GA. Histone H3 lysine 9 methylation and HPlgamma are associated with transcription elongation through mammalian chromatin. Mol Cell (2005) 19(3):381-91. doi:10.1016/j.molcel. 2005.06.011

7. Goldmit M, Ji Y, Skok J, Roldan E, Jung S, Cedar H, et al. Epigenetic ontogeny of the Igk locus during B cell development. Nat Immunol (2005) 6(2):198-203. doi:10.1038/ni1154

8. Mateescu B, Bourachot B, Rachez C, Ogryzko V, Muchardt C. Regulation of an inducible promoter by an HPlbeta-HPlgamma switch. EMBO Rep (2008) 9(3):267-72. doi:10.1038/embor.2008.1

9. Minc E, Courvalin JC, Buendia B. HPlgamma associates with euchromatin and heterochromatin in mammalian nuclei and chromosomes. Cytogenet Cell Genet (2000) 90(3-4):279-84. doi:10.1159/000056789

10. Takada Y, Naruse C, Costa Y, Shirakawa T, Tachibana M, Sharif J, et al. HPlgamma links histone methylation marks to meiotic synapsis in mice. Development (2011) 138(19):4207-17. doi:10.1242/dev.064444

11. Thai TH, Calado DP, Casola S, Ansel KM, Xiao C, Xue Y, et al. Regulation of the germinal center response by microRNA-155. Science (2007) 316(5824):604-8. doi:10.1126/science.1141229

12. Coffey F, Alabyev B, Manser T. Initial clonal expansion of germinal center B cells takes place at the perimeter of follicles. Immunity (2009) 30(4):599-609. doi:10.1016/j.immuni.2009.01.011

13. Pereira JP, Kelly LM, Cyster JG. Finding the right niche: B-cell migration in the early phases of T-dependent antibody responses. Int Immunol (2010) 22(6):413-9. doi:10.1093/intimm/dxq047

14. Rajewsky K. Clonal selection and learning in the antibody system. Nature (1996) 381(6585):751-8. doi:10.1038/381751a0

15. Kaji T, Ishige A, Hikida M, Taka J, Hijikata A, Kubo M, et al. Distinct cellular pathways select germline-encoded and somatically mutated antibodies into immunological memory. J Exp Med (2012) 209(11):2079-97. doi:10.1084/jem. 20120127

16. Crotty S. Follicular helper CD4 T cells (TFH). Annu Rev Immunol (2011) 29:621-63. doi:10.1146/annurev-immunol-031210-101400

17. Nutt SL, Tarlinton DM. Germinal center B and follicular helper T cells: siblings, cousins or just good friends? Nat Immunol (2011) 12(6):472-7. doi:10.1038/ni.2019

18. Linterman MA, Beaton L, Yu D, Ramiscal RR, Srivastava M, Hogan JJ, et al. IL-21 acts directly on B cells to regulate Bcl-6 expression and germinal center responses. J Exp Med (2010) 207(2):353-63. doi:10.1084/jem.20091738

19. Vinuesa CG, Cyster JG. How T cells earn the follicular rite of passage. Immunity (2011) 35(5):671-80. doi:10.1016/j.immuni.2011.11.001

20. Qi H, Cannons JL, Klauschen F, Schwartzberg PL, Germain RN. SAP-controlled T-B cell interactions underlie germinal centre formation. Nature (2008) 455(7214):764-9. doi:10.1038/nature07345

21. Fazilleau N, Mark L, McHeyzer-Williams LJ, McHeyzer-Williams MG. Follicular helper T cells: lineage and location. Immunity (2009) 30(3):324-35. doi:10.1016/j.immuni.2009.03.003

22. Deenick EK, Chan A, Ma CS, Gatto D, Schwartzberg PL, Brink R, et al. Follicular helper $\mathrm{T}$ cell differentiation requires continuous antigen presentation that is independent of unique B cell signaling. Immunity (2010) 33(2):241-53. doi:10.1016/j.immuni.2010.07.015

23. Choi YS, Kageyama R, Eto D, Escobar TC, Johnston RJ, Monticelli L, et al. ICOS receptor instructs $\mathrm{T}$ follicular helper cell versus effector cell differentiation via induction of the transcriptional repressor Bcl6. Immunity (2011) 34(6):932-46. doi:10.1016/j.immuni.2011.03.023

24. Shulman Z, Gitlin AD, Targ S, Jankovic M, Pasqual G, Nussenzweig MC, et al. T follicular helper cell dynamics in germinal centers. Science (2013) 341(6146):673-7. doi:10.1126/science. 1241680 
25. Noble A, Zhao ZS, Cantor H. Suppression of immune responses by CD8 cells. II. Qa-1 on activated B cells stimulates CD8 cell suppression of Thelper 2 responses. J Immunol (1998) 160(2):566-71.

26. Kim HJ, Verbinnen B, Tang X, Lu L, Cantor H. Inhibition of follicular T-helper cells by CD8 $(+)$ regulatory T cells is essential for self tolerance. Nature (2010) 467(7313):328-32. doi:10.1038/nature09370

27. Kim HJ, Wang X, Radfar S, Sproule TJ, Roopenian DC, Cantor H. CD8+ T regulatory cells express the Ly49 Class I MHC receptor and are defective in autoimmune prone B6-Yaa mice. Proc Natl Acad Sci U S A (2011) 108(5):2010-5. doi:10.1073/pnas.1018974108

28. Naruse C, Fukusumi Y, Kakiuchi D, Asano M. A novel gene trapping for identifying genes expressed under the control of specific transcription factors. Biochem Biophys Res Commun (2007) 361(1):109-15. doi:10.1016/j.bbrc.2007.06.161

29. Trowbridge JJ, Sinha AU, Zhu N, Li M, Armstrong SA, Orkin SH. Haploinsufficiency of Dnmtl impairs leukemia stem cell function through derepression of bivalent chromatin domains. Genes Dev (2012) 26(4):344-9. doi:10.1101/gad. 184341.111

30. Horsley D, Hutchings A, Butcher GW, Singh PB. M32, a murine homologue of Drosophila heterochromatin protein 1 (HP1), localises to euchromatin within interphase nuclei and is largely excluded from constitutive heterochromatin. Cytogenet Cell Genet (1996) 73(4):308-11. doi:10.1159/000134363

Conflict of Interest Statement: The authors declare that the research was conducted in the absence of any commercial or financial relationships that could be construed as a potential conflict of interest.

Received: 03 April 2014; accepted: 26 May 2014; published online: 12 June 2014.

Citation: $\mathrm{Ha} \mathrm{N}$, Pham D-H, Shahsafaei A, Naruse C, Asano M and Thai T-H (2014) HP-1 $\gamma$ controls high-affinity antibody response to T-dependent antigens. Front. Immunol. 5:271. doi: 10.3389/fimmu.2014.00271

This article was submitted to B Cell Biology, a section of the journal Frontiers in Immunology.

Copyright (c) 2014 Ha, Pham, Shahsafaei, Naruse, Asano and Thai. This is an openaccess article distributed under the terms of the Creative Commons Attribution License (CC BY). The use, distribution or reproduction in other forums is permitted, provided the original author(s) or licensor are credited and that the original publication in this journal is cited, in accordance with accepted academic practice. No use, distribution or reproduction is permitted which does not comply with these terms. 